\title{
Analyzing the influence of economics on management education and practice: a criticism through the concept of development
}

\author{
José Antonio Puppim de Oliveira ${ }^{1}$
}

\begin{abstract}
This article is a criticism of the neoclassical economics influence on theories of management using the experience and lessons from the evolution of the debates in development studies. I argue that this influence has introduced values that are incompatible with the values of what could be a socially responsible society in a modern view of what is development. The article firstly examines the evolution of the debates of the concept of development, as they moved from being forums dominated exclusively by economists - who saw development as synonym of economic growth - to a multi and interdisciplinary debate over several dimensions of development, including social, environmental and democracy issues. Secondly, it criticizes management theories based on neoclassical economics through the experience of the development debate. I argue that management theories based on economics see the management solutions as a one-way alternative (market- based solutions), influence the thinking of both the means and the ends of organizations, and have propagated a series of values that are not compatible with a socially developed society.
\end{abstract}

KEYWORDS: development, neoclassical economics, teaching curriculum, ethics, values.

RESUMO: Este artigo é uma crítica à influência da economia neoclássica em teorias de gestão usando a experiência e lições da evolução dos debates em estudos de desenvolvimento. O autor argumenta que esta influência vem introduzindo valores que são incompatíveis com os valores do que poderia ser uma sociedade socialmente responsável em uma versão moderna do que é desenvolvimento. O artigo primeiramente examina a evolução dos debates do conceito de desenvolvimento, deixando de ser fóruns dominados exclusivamente por economistas - que viam desenvolvimento como sinônimo de crescimento econômico - passando para um debate multi e interdisciplinário sobre diversas dimensões do desenvolvimento, incluindo questões sociais, ambientais e democráticas. Em segundo lugar, o artigo critica teorias de gestão baseadas na economia neoclássica por meio da experiência do debate sobre desenvolvimento. O autor argumenta que as teorias de gestão baseadas na economia vêem as soluções de gestão como uma alternativa de via única (soluções baseadas no mercado), influenciando o pensamento tanto dos meios quanto dos fins das organizações, e propagando uma série de valores que não são compatíveis com a sociedade socialmente desenvolvida.

PALAVRAS-CHAVE: desenvolvimento, economia neoclássica, currículo de ensino, ética, valores.

Pesquisador sênior e diretor assistente do Instituto de Estudos Avançados da Universidade das Nações Unidas (UNU-IAS), no Japão. Doutor em Planejamento pelo Massachusetts Institute of Technology, nos Estados Unidos. E-mail: joseantonio_puppimdeoliveira@ yahoo.com.

CADERNOS GESTÃo PÚBLICA E CIDADANIA, V. 14, N. 55 - JUL./DEZEMBRO DE 2009 


\section{Introduction}

This article is a conceptual criticism of the influence of economics ${ }^{2}$ on the theories of development and management and consequently on the formation of managers and on practice. The paper points that this influence has introduced (consciously and unconsciously) values that are incompatible with the values of what could be a "good society" (developed society) in a modern view of what is development. It tries to bring the development literature to the management education debate in order to improve social responsiveness of managers.

Business scandals and corruption cases in government continue to pop up all over the developing and developed world, sometimes involving former management school students. Moreover, the rapid economic growth and prosperity in the last years have not been able to solve social, environmental and security issues (UN, 2005). Even though many management schools, governments and companies have made considerable efforts to introduce ethics and more social and environmental aspects in their curricula and policies, those efforts may not be enough to contain the tremendous impacts of economic theory on how to think the functioning of society and management practice. Not even the growing importance of issues like stakeholder management, participation, transparency, ethics and sustainability, helped to stop ethical and social problems, because even those issues are taught with an "economicist" bias.

A key point of this paper is the link between management, society and development. We cannot think about development "one-dimensionally”; it means regarding only the economic dimension: nor in the ends neither in the means of development. Interestingly, the initial focus of American management schools was on preparing managers to take care of society interests, both economic and non-economic interests (GALBREATH, 2006). Later on, because of he broad influence of shareholder and economic theories in management, management schools moved their curricula to teach how people are self-interested and need to be regulated, neglecting society and non-economic interests. This influenced public management practice and schools through the New Public Management (NPM).

The concept of development evolved from being a pure synonym of "economic growth" before the 1950s to a much complex concept nowadays. Today, there is a growing consensus that development involves several dimensions of individuals and society, such as social, environmental, political and ethical aspects. Society is increasingly interested in these other dimensions of development, such as political dimension (freedom), social sphere (distribution

2 I use 'Economics’ as synonym of Neoclassical Economics when not specified. 
of the assets) and environmental aspects. Therefore, a "developed society" (or "good society") should have individuals (and organizations) with values that permeate all these dimensions to think both in the ends and in the means of development.

Not differently from Economics and Management, the field of developmental studies is permeated with ethical values. The different interpretations of what is development or wealth is such a big debate because less of disagreement on the "scientific methods" of defining or calculating development and more because exactly the definitions and means are fully embedded with ethical values.

The present article is divided into two basic parts. Firstly, I examine the evolution of the debates of the concept of development, as they moved from being forums dominated exclusively by economists, who saw development as synonym of economic growth, to a multi and interdisciplinary debate over several dimensions of development. Secondly, I criticize Management Theories based on Neoclassical Economics through the experience of the development debate. I argue that management theories based on economics see the management solutions as a one-way alternative (market-based solutions), influence the thinking of both the means and the ends of organizations and have propagated a series of values that are not compatible with a developed society.

\section{The evolving concept of development}

The concept of development has been the main reason of a long debate in academia and practice involving several disciplines, including economics, sociology, anthropology, political science and planning. Although there is no general consensus about both the ends of and the means for development, the field of development studies evolved from an economic centered debate led by economists to a more multi and interdisciplinary debate, which included other dimensions for thinking development, such as the social, environmental, ethical and political dimensions (HARRISS, 2002; KANBUR, 2002).

The initiatives of trying to understand development in a more organized field of knowledge started after the Second World War, when economists, in the so called field of development economics, searched for a way to reconstruct Europe and boost the economy of developing countries in other continents (INGHAM, 1993). By the time development was synonym of economic growth, the main idea behind the minds of the first development economists was that economic growth patterns could be copied and replicated from the experience in the $19^{\text {th }}$ century of the development countries in Europe, USA and Japan. There was the idea that paths

CADERNOS GESTÃo PÚBLICA E CIDADANIA, V. 14, N. 55 - JUL./DEZEMBRO DE 2009 
of economic development were linear, and every country had to follow the same paths. For example, the economic historian Rostow (1959-1971) had built an influential theory that looked at the development history of the main development countries and classified development as a path to be achieved escalating five stages, from the traditional society to the age of high mass consumption. Later on, this theory was questioned by several scholars with different points (GERSCHENKRON, 1966; HIRSCHMAN, 1958; 1970). Some found that the developed countries had actually different paths of economic growth. Gerschenkron argued that the industrialization of late comers' economic powers in Europe, such as Germany, differed significantly from the first movers of the industrial revolution, such as Great Britain. Even though the idea of linearity in development studies has still a stronghold, as the aim of developing countries are to be like the today's developed countries, many scholars and practitioners agree that there are different conceptions and paths to reach development (HIRSCHMAN, 1958).

The economic dimension of development was hegemonic until the 1970s. Development was considered economic growth. The level of development was measured by the typical economic indicators, such as Gross Domestic Product (GDP) and GDP per capita. Even though other dimensions, such as social issues, were mentioned as part of the end or means of the development, they were considered consequences of economic dimensions. For example, it would be normal to have an increase in income inequalities as a country grew economically, but it was assumed that they would be automatically reduced later on, when that country reached high economic levels (the principles of the Kuznets curve). However, studies showed that other countries, like Brazil, had enormous continuous economic growth in the 1960s and 1970s, but the benefits were captured mostly by the richest and even some poor people were worse off in the process (FISHLOW, 1972).

Thus, in the process of changing the concept of development, in the 1970s and 1980s, scholars and practitioners thought that other dimensions of the economic sphere were necessary to explain what development, beyond the mere economic growth was. Basic needs, poverty reduction and income distribution became part of the discourse and actions. Even some of the most conservative development organizations, such as the World Bank, moved its agenda of development to consider the social dimensions of economic development (WORLD BANK, 1972). Nowadays, economic growth without redistribution of wealth is not considered good for development, as paths of economic development must include also growth with income distribution. However, income distribution and basic needs are still centered in a pure economic materialistic (good-oriented) view of development. Some social scientists and 
development economists, like Amartya Sen (1999), argued that development should be centered in the human part of the people, more specifically on the human freedom. As a result of these debates, development became a broader concept related to the human freedom (SEN, 1999). For measuring other dimensions of development, the United Nations Development Programme (UNDP) has created the Human Development Index (HDI) to challenge the economic-oriented development index that existed until the 1980s. HDI measures development as a proxy of not only economic well-being, but also other factors, such as longevity and literacy. The UNDP launched HDI in 1992 (UN, 1992) and since then it became the main indicator of development in practice.

In the 1980s and 1990s, others issues arose in the agenda of development, such as democracy and environmental protection. Environmental issues were the main concern of the conference of the United Nations Conference for Human Development held in Stockholm in 1972, when the industrialized countries, under pressure of Non-governmental Organizations (NGOs), recognized that economic growth had come at the expense of the environmental quality. In 1987, the Brundtland Report popularized the concept of Sustainable Development, which is defined as long term development in the economic, social and environmental dimensions (UN, 1987). The Environment was an important asset to be preserved for the sake of the next generations and for a sustained social and economic development.

Democracy was another dimension that came to the development debates in the 1980s and 1990s. Many developing countries, especially in Latin America and Eastern Europe, went through democratization processes starting in 1980s. Dictatorships and centralized governments were replaced with elected governments. Democracy and political rights were a fundamental sphere of human development, as many defended (SEN, 1999). Democracy also was valued not only as an end of development, but as well as a means to achieve sustained economic growth and distribution, as countries that had long periods of economic growths in 1980s, including many developed countries, had more democratic systems of government (WORLD BANK, 1989). Also, democracy was said to be fundamental to build social capital and good governments and systems of governance (PUTNAM, 1994).

However, even though the concept of development moved away from the uni-dimensionality of aggregate economic indicators in the last decades and as consequence development studies have become more than a mere field of economics (development economics), economics has been the most influential discipline in the debates of development along the years. The lost of economics in influencing the definition of the ends of development since the 1970s was not enough to impede the advances of economics in influencing the means to achieve 
development. For example, the Washington Consensus, in the 1980s and 1990s, was the main axe for the social and economic reforms designed for many development countries to insert themselves in the globalization process (GORE, 2000; RODRIK, 2003). It has set a series of institutional changes - such as deregulation of markets, privatization and fiscal austerity - to supposedly reduce the role of governments to a minimum and increase the role of markets in order to boost social and economic development (WILLIAMSON, 1980). Pressured by multilateral organizations, as the International Monetary Fund (IMF) and the World Bank, many developing countries, especially in Latin America, engaged in a series of reforms based on the Washington Consensus. The main result were economic crises - which basically led literally to the bankruptcy of several countries especially those that implemented the reforms more seriously - followed by social and political unrests, like in the case of Argentina and Ecuador (STIGLITZ, 2002), as well as the appearance of populist leaders like Hugo Chavez.

New Public Management (NPM) is another influential paradigm of economics in the means of development. Based on mainstream economics and game theory, NPM brings to state and public organizations the dynamics of incentive systems of private enterprises, such as the introduction of performance based indicators and individual rewards based on it. The principles of NPM were applied in the reforms of public organizations and systems since the Thatcher era in the U.K, and later translated by development organizations to be applied in developing countries. Up to now, the results of reforms based on NPM in developing countries have been questioned. In Brazil, for example, the reforms inspired in the NPM tried by the former government of Fernando Henrique Cardoso led many public employees rush for retirements as they fear changes in the public service rules, which skyrocket the deficit in the public pension system, and there is no indication that the reforms reached the expected efficiency results in the public machine. NPM has shown, so far, that is one more good idea in theory and a bad one in practice for developing countries. Therefore, approaches based on economics are also limited to provide solutions to the means of achieving goals of social and economic development.

What is a developed society? The answer to that question is always evolving, as new approaches and dimensions to development appear. Actually, this dynamic evolution of the concept of development is even more desirable than a static definition, as it can adapt to the different conditions, the changes in societies and the ways they are understood. There is also a stress on the ethics of development by some authors (GOULET, 1992; SEN, 1999), as they claim that development policies are not value free and there are ethical considerations when decisions are taken by individuals and society. Thus, even though the concept evolves, the modern debates on development give certain directions and ethical principles to determine 
what it is. First, development is not economic growth; other dimensions of development are important as well, such as social, environmental and political (SEN, 1999). Second, both the ends and the means of development are important. Development should take place with priority to the poor and weak, equality of opportunities and distribution of resources and protection of the environment (INGHAM, 1993). Third, there is more than one path to develop. Several alternatives to development exist and each society, or even individuals, should find the best way to develop. Fourth, development should be centered in human development. Individuals should have satisfied their material needs, have political and other freedoms, as their human rights. Fifth, democratic principles should be in place as a means and end of development at the macro and micro level. Trust should be in place to help develop the relations among individuals and organizations.

As both means and ends matter for thinking and promoting development, the principles above are important to be introduced in organizations and individuals to have long term impacts on society. If they are not in that place in the process of development, the ends will possibly fail as well.

\section{A criticism of management theories based on economics through the lenses of development}

The field of mainstream economics has been very influential in management, both in theory and in practice, especially in the last decades when economics-based MBA teaching has boomed in the North America and around the world (MINTZBERG, 2004). However, recently scholars have challenged the way schools engage with society (BOYLE, 2004; BOEHM, 2005) and teach management (DONALDSON, 2002; PFEFFER and FONG, 2002), especially management theories based on economics (GHOSHAL, 2005; FERRARO et al, 2005). This comes in a time management when academia is still trying to understand "what went wrong?” and "how to form more ethical management students?”, after a landslide of scandals in the business world - as happened with Parmalat, Eron and Worldcom -, many times involving former MBA graduates from some of the leading management schools.

The relation between management, society and development had been much closer in the past. Early management education intended to prepare future managers to defend the interest of society (GALBREATH, 2006), including non-economic issues. As shareholder interest theories and neoclassical economics became popular, the focus of management education changed. Management schools now form managers to think organizations as a bundle of self-interested economic rational individuals. In the 1970s, management schools started

CADERNOS GESTÃo PÚBLICA E CIDADANIA, V. 14, N. 55 - JUL./DEZEMBRO DE 2009 
to include more ethics content in their curricula, but there is still a debate that ranges over whether teaching those topics has any effective change in managers' behavior or what is the best way to teach ethics (SIMS and FELTON, 2006; RITTER, 2006). My argument is that those topics may not be enough to counterbalance the rational maximizer behavior propagated by all other courses and contents based on neoclassical economics.

Thus, this section analyzes the limitations of management theories based on neoclassical economics through the less of the lessons of the evolution of the debates on development. First, the article examines that economics, and its management theories, gives a one-way linear solution to management issues (market-based private solutions). Experience in development studies has shown that there is several ways to real-world problems. This one-way approach is limited, and even dangerous in certain situations. Second, the section analyzes the influence of economics in analyzing both the ends and means of an organization. I mention that dealing with the influence of mainstream economics in the ends of organizations is less complicated than dealing with the means. Third, I argue that mainstream economics, and its management theories, has propagated values that are incompatible with values of a developed society, in the modern way of thinking development.

\section{The one-way solution of neoclassical economics}

The idea the market solutions are the best alternatives for solving problems of efficiency and distribution of resources and it is the basis of the modern economics. Adam Smith (1776) created the concept of the "invisible hand", in which self-interested individuals could lead to optimal economic results for society both in terms of economic growth as well as distribution of resources. Friedman (1977) defended the extreme use of the invisible hand. He supported free market solutions would be preferable for society in any situation, from improving education systems to combat racism, even recognizing certain roles to government and the limitations of the economic theory in practice. Even the realm of New Institutional Economics (NIE), which many see as the "missing link" between economics and the real-world, are centered in the creation of well-functioning market rules as solution for economic development (NORTH, 1990).

However, there are severe limitations in the use of market solutions for solving many societal and organizational problems, which can even be aggravated by this use. On the one hand, there are the intrinsic problems even mainstream economists recognize in their theories, such as how to deal with distributional effects and inequality; individuals are different consequently the performance in a market-based system would be different, generating rich and poor people.

CADERNOS GESTÃo PÚBLICA E CIDADANIA, V. 14, N. 55 - JUL./DEZEMBRO DE 2009 
On the other hand, there are a series of other problems regarding structure of market functioning recognized by mainstream economists. The supposedly effects of the "perfect" invisible hand (or perfect market), appears when several conditions are in place, such as perfect competition, symmetry of information and rationality of economic actors (SEN, 1977). They are necessary to be in place for validating theories of economics and its effects. Nonetheless those conditions are non-existent in the real world, even in the most dynamic markets such as stock markets. Most of other real-world situations do not get even close to satisfy any of the conditions. Therefore, economics are very important to theorize on how the world would function under extreme (and unreal) conditions, but poor to understand real-world phenomena of management (which goes beyond economics), and much more to provide solutions to its problems.

However, mainstream economics is as much an ideology as it is a science, when trying to find solutions for development and management problems. The trend of neoclassical economists is to find market-based, private solutions to all societal problems, not because it is supported by evidence, but by ideology. For example, this is clear when Friedman (1977) discusses monopoly. He argued that it is preferred a private monopoly than a public monopoly, even though he recognizes that there is no evidence the former is better for society or for the economy. Actually, critical economists, like Nobel Prize Joseph Stiglitz, argue that there is no evidence in practice that public organizations are less efficient than private ones (STIGLITZ, 2001), only in economics and management theory.

The consequences of applying solutions of mainstream economics to real world problems can lead to catastrophic results, such as the case of the reforms based on the Washington Consensus in Latin America (see the previous section). Economists, especially in the multilateral organizations that promoted the consensus, assumed that markets would be "more perfect" with the reforms and thus foster economic prosperity. However, they just destroyed the fragile (but existent) real-world rules that regulated the economic actors and replaced with non-functioning and ineffective market rules, which led to economic stagnation or even chaos.

Regarding management theories, many of the scandals resulted from the design of managers' incentives based on companies' results. Those were one of the applications of the principles of the agency theory - which are strongly influenced by mainstream economics - to solve governance conflicts between owners and managers. However, this led to managers to become more self-interested and ultimately pay them off to take the risk of making up balances to increase their results.

CADERNOS GESTÃo PÚBLICA E CIDADANIA, V. 14, N. 55 - JUL./DEZEMBRO DE 2009 
Therefore, when organizations and rules to govern them are shaped by theoretical concepts that are unreal and unachievable in the real world, the results can be disappointing, as they were not expected. The understanding of how the real-world in real situation and conditions function are fundamental to create real-world solutions.

\section{Economics' influence in shaping the means and ends of managing organizations}

The influence of mainstream economics in management could be divided into two types connected respectively to the end and the means of managing an organization. The problem in the ends would be related to the utility maximizing goal (economic or political) of a typical organization.

The second set of problems (means) seems to be more complicated. Neoclassical economics have permeated the way individuals and organizations are understood and consequently how they should be managed. Especially after the rise of agency and game theory, management schools and specialized media have propagated the idea of individuals as being selfish utility maximizers, so they should be treated as such by the others and by organizational rules. The result is the spread of certain mainstream economics values on how we create rules for organizations and societies (see below and Table 1), which are incompatible with the modern concepts of development. In the end, this can lead individuals to actually behave like selfish utility maximizers, in order to survive or prosper under the rules created by managers, in a behavior previewed by the theory.

Fostering individuals and organizations to behave in a manner that is incompatible with a behavior expected in a developed society, leads to a mal-functional society and consequently mal-functional organizations and individuals.

\section{The influence of economics values in societal values}

One of the major differences between social and natural sciences is the relation between object and subject. Theories in social sciences not only try to understand a certain object, but their ideas can influence the way the object functions, because humans are influenced by those ideas. When one is exposed to theories of social sciences, it changes the way of perceiving the world and consequently its ideas and behavior.

One of the most perverse consequences of the influence of mainstream economics in management and other social sciences is the spread of their values in individuals and,

CADERNOS GESTÃo PÚBLICA E CIDADANIA, V. 14, N. 55 - JUL./DEZEMBRO DE 2009 
consequently, in the way organizations and even States function. Experiment with economists and students of economics have shown that they are much more self-interested and leaned to competition than people of other disciplines (MILLER, 1999). Managers can acquire intrinsic values of economics when they are exposed to theories based on mainstream economics without a proper critical view of its many limitations and possible alternatives.

Economics and Management are applied to social sciences. Sciences, especially in social science, are not value-free. Even when researchers try to put their research as "neutral" and "purely scientific", there are many aspects of it that are shaped by their ethical values. The own view of researchers that truly believe social science can be "purely scientific" is embedded with some ethical values; exactly because of their beliefs that science is "value-free". When (scientific) theories are propagated, they influence the values of individuals and organizations and consequently their behaviors. When economic thought through management theories propagates issues like selfishness, unlimited competition and maximization behavior, it is propagating values that shape individuals and societies.

The values disseminated by mainstream economics and the management theories based on them are not compatible with the values of what a developed society in modern thinking expects for individuals and, consequently, for organizations or States. Mainstream economics assumes that individuals are basically selfish and utility maximizing; they are sensible only to the ethics of market rules and stress the importance of rewarding the most efficient and strongest. Market-based solutions are the only way of achieving economic and social goals. On the other hand, the modern concept of development stresses a series of values that are not present in mainstream economics - such as the importance of equality in the distribution of economic resources and non-economic ends and goals of individuals and societies. Table 1 summarizes most of the value difference between economics and developed society. The construction and maintenance of a developed society depends on the organizations and their managers, which are molded by the values they learn at school and other informal means (news etc). For example, individuals in mainstream economics are based on a maximization behavior, which sometimes is not in the interest of a broad society, while in a developed society satisfaction of individual needs of all is the goal.

Therefore, the values of mainstream economics are propagated at the expense of values of a developed society when principles of mainstream economics are taught without proper criticism at universities and are propagated by the media. This influences the behavior of individuals and, consequently, the behavior of organizations. When those individuals are potential managers, the results can be even more critical, as they are more influential in shaping organizations and other individuals.

CADERNOS GESTÃo PÚBLICA E CIDADANIA, V. 14, N. 55 - JUL./DEZEMBRO DE 2009 
Table 1 - Values of Mainstream Economics versus Development

\begin{tabular}{|l|l|}
\hline \multicolumn{1}{|c|}{ Values propagated by mainstream economics } & \multicolumn{1}{c|}{ Values of a developed society } \\
\hline Selfishness & Importance of sharing \\
\hline $\begin{array}{l}\text { Competition as the main solution for distribution of } \\
\text { resources }\end{array}$ & Cooperation and trust \\
\hline Maximization behavior & Satisfaction of individual needs of all as a goal \\
\hline Disregard for equality & Stress of social and economic equality \\
\hline Disregard for the poor and weak & Social sensitivity for the poor and weak \\
\hline Individual decisions (and consequently power) & Democratic and participatory decisions \\
\hline Little regard to ethics and morality & Moral correctness with pluralism \\
\hline Ends (bottom line) that matter most & Means matter as much as the ends \\
\hline Stress of Utilitarism & Other ethical concerns also matter \\
\hline One way to achieve the ends & Several paths to achieve the end \\
\hline $\begin{array}{l}\text { Disregard for managing common resources, except } \\
\text { when there are price signals }\end{array}$ & $\begin{array}{l}\text { Managing the commons resources as fundamental } \\
\text { for sustainability }\end{array}$ \\
\hline
\end{tabular}

\section{Conclusions}

Economists were important to shape the debate in management and developmental studies. Even though, neoclassical economists try to prove the "scientificism" of their theories and methods, there are many shortcomings. Nobel prizes like Joseph Stiglitz and Amartya Sen, pointed out many of those shortcomings, such as the limitations of the economic theory for dealing with distributional issues, rationality and perfect competition. However, neoclassical economists, consciously and unconsciously, have succeeded in introducing a series of concepts that can influence ethical values in society, such as the need or desirability of agent selfishness, preference of maximization and the need of fomenting competitive behavior for almost every aspects of the management life. Many of these values go against the values of what a "developed society" would defend according to a broader view of development, values such as the social sensitivity for inequalities, the attitude in favor of sharing common resources, the stress to moral correctness and the placement of the means of wealth development (and not only the ends) as fundamental parts of the process of human development. The challenge is how to introduce these values in order to shape attitude and behavior in management, both private and public.

The main theories of management, especially those derivate from neoclassical economics, have many shortcomings and introduce values that are not compatible with what a developed 
society should be, but they still persist (PFEFFER, 2005). On the other hand, there is no consistent alternative theory of development, or even a country case that could be a good example of a process of development. Even the so-called development countries receive harsh criticisms with global warming and consumption patterns, which cause global problems. Therefore, we need more research efforts to develop alternative paths to think both the means and ends of development.

If we want to influence knowledge and practice of development and management, we have to create alternative theories, which must be consistent, but with ethical values different from those propagated by the neoclassical economics. It does not mean that alternative theories do not exist, they do. However, they need to be consolidated to be more influential in practice as much as neoclassical economics and its derivatives. In order to build knowledge in the field of management and development, we need to teach and research the most influential theory, neoclassical economics, but with a much critic approach than those given by management schools. Students have to understand that theories in social science are shortcomings or interpretations of the World, and all, without exceptions, are limited. Teaching how to identify shortcomings in theories can help students to be sharp in their critics and their own knowledge building in management, so in the future we will have more practice based on those more critical views. In this way, we would be teaching not only how to be good managers, but also how to be part of a more developed society.

\section{References}

BOEHM, A. The participation of businesses in community decision making. Business Society, v. 44, n. 2, p. 144-177, 2005.

BOYLE, M. Walking our talk: business schools, legitimacy, and citizenship. Business Society, v. 43, n. 1, p. 37-68, 2004.

DONALDSON, L. Damned by our own theories: contradictions between theories and management education. Academy of Management Learning \& Education, v. 1, n. 1, p. 96-106, 2002.

ECONOMIST, the. The good company. The Economist, 22.jan.2005.

FERRARO, F.; PFEFFER, J.; SUTTON, R. I. Economics language and assumptions: how theories can be self-fulfilling. Academy of Management Review, v. 30, n. 1, p. 8-24, 2005. 
FISHLOW, A. Brazilian size distribution of income. American Economic Review, v. 62, n. 2, p. 391-410, 1975.

FRIEDMAN, M. Capitalism and freedom. Chicago: The University of Chicago Press, 1977.

FRIEDMAN, M. The social responsibility of business is to increase its profits. The New York Times Magazine, 13 sept. 1970.

GALBREATH, J. Are organization researchers too obsessed with the economic responsibility of the firm? Journal of Business Ethics, v. 65, n. 3, p. 287-295, 2006.

GERSCHENKRON, A. Economic backwardness in historical perspective. Boston: Harvard University Press, 1966.

GHOSHAL, S. Bad management theories are destroying good management practices. Academy of Management Learning \& Education, v. 4, n. 1, p. 75-91, 2005.

GORE, C. The rise and fall of the Washington consensus as a paradigm for developing countries. World Development, v. 28, n. 5, p. 789-804, 2000.

GOULET, D. Development: creator and destroyer of values. World Development, v. 20, n. 3, p. 467-475, 1992.

HARRISS, J. The case for cross-disciplinary approaches in international development. World Development, v. 30, n. 3, p. 487-496, 2002.

HIRSCHMAN, A. Exit, voice and loyalty: responses to decline in firms, organizations and states. Boston: Harvard University Press, 1970.

HIRSCHMAN, A. The strategy of economic development. New Haven: Yale University Press, 1958.

INGHAM, B. The meaning of development: interactions between new and old ideas. World Development, v. 21, n. 11, p. 1803-1821, 1993.

KANBUR, R. Economics, social science and development. World Development, v. 30, n. 3, p. 477-486, 2002.

MILLER, D. T. The norm of self-interest. American Psychologist, v. 54, n. 12, p. 1053-1060, 1999.

MINTZBERG, H. Managers not MBAs. San Francisco: Barret-Koehler, 2004.

NORTH, D. Institutions, institutional change and economic performance. Cambridge: Cambridge University Press, 1990. 
PFEFFER, J. Why do bad management theories persist? A Comment on Ghoshal. Academy of Management Learning and Education, v. 4, n. 1, p. 96-100, 2005.

PFEFFER, J.; FONG, C. T. The end of business schools? Less success than meets the eye. Academy of Management Learning \& Education, v. 1, n. 1, p. 78 -95, 2002.

PORTER, M. E.; VAN DER LINDE, C. Green and competitive: ending the stalemate. Harvard Business Review, v. 73, n. 5, p. 120-134, 1995.

PUTNAM, R. D.; LEONARDI R.; NANETTI, R. Y. Making democracy work: civic traditions in modern Italy. Princenton: Princeton University Press, 1994.

RITTER, B. A. Can business ethics be trained? A study of the ethical decision-making process in business students. Journal of Business Ethics, v. 68, n. 2, p. 153-164, 2006.

RODRIK, D. Growth strategies. Cambridge: National Bureau of Economic Research, working paper 10050, 2003.

ROSTOW, W. W. Politics and the stages of growth. Cambridge: Cambridge University Press, 1971.

ROSTOW, W. W. The stages of economic growth. American Economic Review, v. 12, n. 1, p. 1-16, 1959.

SEN, A. K. Development as freedom. New York: Random House, 1999.

SEN, A. K. Rational fools: a critique of the behavioral foundations of economic theory. Philosophy and Public Affairs, v. 6, n. 4, p. 317-44, 1977.

SIMS, R. R.; FELTON, E. L. Designing and delivering business ethics teaching and learning. Journal of Business Ethics, v. 63, n. 3, p. 297-312, 2006.

STIGLITZ, J. E. Globalization and its discontents. London: Penguin Books, 2002.

STIGLITZ, J. E. Improving efficiency and responsiveness of the public sector: lessons from recent experience. In: CONGRESO LATINO AMERICANO DE DESARROLLO, 6. Buenos Aires. 2001. Buenos Aires: CLAD, 2001.

UN - United Nations. Human development report. New York: Oxford University Press, 1992.

UN - United Nations. Our common future. New York: Oxford University Press, 1987.

UN - United Nations. The inequality predicament: report on the World Social Situation, reported at United Nations. New York: Oxford University Press, 2005.

CADERNOS GESTÃo PÚBLICA E CIDADANIA, V. 14, N. 55 - JUL./DEZEMBRO DE 2009 
WILLIAMSON, J. G. Inequality poverty and history. Cambridge: Basil Blackwell, 1980.

WORLD BANK, the. Social indicators of development. Baltimore: John Hopkins University Press, 1972.

WORLD BANK, the. Sub-Saharan Africa: from crisis to sustainable growth. Washington: The World Bank, 1989.

Artigo recebido em 10/12/2009. Aprovado em 14/12/2009. 